\title{
Antisense Phenotypes Reveal a Functional Expression of OsARF1, an Auxin Response Factor, in Transgenic Rice
}

\author{
Kotb A. Attia ${ }^{1,2}$, Amr F. Abdelkhalik', Megahed \\ H. Ammar ${ }^{1}$, Chun Wei ${ }^{2}$, Jinshui Yang ${ }^{2}$, David A \\ Lightfoot $^{3}$, Wagih M. El-Sayed ${ }^{4}$ and Hany A. El- \\ Shemy ${ }^{5 *}$
}

${ }^{1}$ Rice Biotechnology Lab., Rice Research \& Training Center, Sakha, Kafr EL-Sheikh, 33717, Egypt

${ }^{2}$ Institute of Genetic Engineering, School of Life Science, Fudan University, Shanghai, 200433, China

${ }^{3}$ Plant Biotechnology and Genomics Core-Facility, Department of Plant, Soil, and Agricultural Systems, Southern Illinois University, Carbondale, IL 62901-4415, USA

${ }^{4}$ Department of Genetics, Faculty of Agriculture, Alexandria University, Alexandria, Egypt

${ }^{5}$ Faculty of Agriculture Research Park (FARP) and Biochemistry Department, Faculty of Agriculture, Cairo University,12613 Giza, Egypt

Received 13 August 2008

Revised 22 September 2008

Accepted 24 October 2008

\begin{abstract}
OsARF1 is the first full-length member of auxin response factor $(A R F)$ gene family to be cloned from monocot plant. Using quantitative RT-PCR this study found that, the transcript abundance of OSARF1 was significantly higher in embryonic tissues than in vegetative tissues. To investigate the effect of OsARF1 on the phenotype of rice, a cDNA fragment of OsARF1 was inserted in inverse orientation to the $35 \mathrm{~S}$ promoter in vector pBin438 to produce an antisense (AS) construction. The ASOsARF1 construct was transferred into rice (Oryza sativa L. japonica) calli via Agrobacterium tumefaciensmediated transformation. Molecular analysis of transgenic plants showed that the functional expression of OsARF1 was inhibited at mRNA level efficiently. The AS-OsARF1 plants showed extremely low growth, poor vigor, short curled leaves and tillered but were sterile. Therefore, the OsARF1 was shown to be essential for growth in vegetative organs and seed development.
\end{abstract}

Keywords: auxin response factor 1(ARF1), antisense technology, gene transformation, functional genomics, Oryza sativa

Abbreviations: ARF, auxin response factor; RT-PCR,
reverse transcriptional polymerase chain reaction;

*For correspondence: helshemy@hotmail.com
AS-DNA/RNA, antisense DNA/RNA; RACE, rapid amplification of cDNA end.

\section{Introduction}

Auxin is one of the two most important plant hormones, and regulates various growth and developmental processes by controlling the expression of auxin-response genes (Ulmasov et al., 1995). Auxin responsiveness is conferred to several genes by conserved promoter elements, termed 'auxin-responsive elements' (AuxRE) AuxRE promoter elements are bound by a new class of plant-specific transcription factors, named auxin response factors (ARFs) (Ulmasov et al., 1997a). Because of the extremely low expression of genes encoding ARFs, none were isolated until 1997. The first auxin response factor (ARF1) was isolated from Arabidopsis (Ulmasov, et al., 1997a). It was found that all members of the ARF gene family have an amino-terminal DNA-binding domain and most contain a C-terminal region with two conserved domains, which are involved in homo-and hetero-dimerization (Ulmasov et al., 1999). In Arabidopsis, it has been reported that the ARF proteins are encoded by a gene family with 23 members and some of them have been shown to repress or to activate expression of reporter genes with an AuxRE promoter element (Ulmasov et al., 1999a; Remington et al., 2004; Okushima et al., 2005). Recently, the first full-length $A R F$ gene of a monocot plant was cloned from rice (Frank et al., 2002). Several rice ARF family transcriptional regulators were also identified homologous to Arabidopsis ARF1 (Waller et al., 2002). From genome sequences many ARF genes in Arabidopsis and in rice have been isolated (Akila et al., 2004; Wang et al., 2007). Many of the $A R F$ genes mediate up-regulation by auxin but some cause down-regulation by auxin (Ulmasov et al., 1999). Different amino acid biases in mediate regions of $A R F$ genes family were shown to underlie the ability to cause up or down regulation to downstream genes, by fusion protein experiments (Ozga et al., 2002). The protein product of a rice auxin response factor OsARF1 was shown to be localized in nucleus with the OsARF1: GFP fusion protein (Waller et al., 2002).

The data on $A R F$ genes family was accumulating rapidly in last few years, but there are still few reports on their effects on phenotype. Most (13/18) ARF genes when knocked out in $A$. thaliana plants showed no obvious phenotypic change except the previously identified arf2/hss, arf3/ett, arf5/mp, and arf7/nph4 mutants (Okushima et al., 2005). arf mutations can affect gynoecium patterning (ARF3); impaired hypocotyl response to blue light, growth and auxin sensitivity (ARF7); the formation of vascular strands and embryo axis formation (ARF5); suppression of the hookless phenotype and hypocotyl bending (ARF2); hypocotyl 
elongation, and auxin homeostasis (ARF8). Some double mutants with a phenotypic single gene knock out family members may show new phenotypes. For example, the arf7 arf19 double mutant was severely impaired in lateral root formation and showed abnormal gravitropism in both hypocotyls and roots.

To test the functional analysis of a previously cloned gene OsARF1 we generated transgenic plants expressing an antisense (AS) copy of OsARF1 cDNA in rice. Using a combination of morphological and molecular analysis, we show that AS-copy of OsARF1 plants exhibits low growth and sterility.

\section{Materials and methods}

\section{Germination assays and tissue culture}

Rice callus was induced from the seeds of Zhonghua11 (Oryza sativa L. japonica) on MS medium that contained MS salts (Sigma, St Louis, MO, USA), $2 \mathrm{mg} / \mathrm{l}$ 2,4-D, B5 vitamins and $3 \%(\mathrm{w} / \mathrm{v})$ sucrose. The primary callus was dissected from the seeds and placed on the same MS medium for 2 weeks. The subcultured callus was separated from the primary callus. After two weeks, one part of subcultured callus was placed on the same MS medium to regenerate the tertiary callus (designated as embryogenic callus) and another part was placed on the MSD medium (containing MS salt, $2 \mathrm{mg} / \mathrm{l} 6-\mathrm{BA}$, $0.5 \mathrm{mg} / \mathrm{l}$ kinetin, B5 vitamins and $3 \%$ sucrose), on which the callus was cultivated until a large number of green dots were growing (designated as differentiating callus). The embryogenic callus and the differentiating callus were collected at the same time for RNA extraction. The sterilized rice seeds germinated and grew to the seedling stage at $25^{\circ} \mathrm{C}$ under a $16-\mathrm{h}$ light/8-h dark photoperiod. After the 2-leaf stage, the seedlings were transplanted into the field. The leaves and roots at the 4-leaf stage were collected. Additionally, at the reproductive stage, the young panicles that were shorter than $5 \mathrm{~mm}$ in length were collected and immediately frozen in liquid nitrogen and stored at $-80^{\circ} \mathrm{C}$.

\section{RNA extraction and reverse transcription}

Total RNA was extracted from different rice tissues by using Trizol reagent (Invitrogen, Karlsruhe, Germany) according to the manufacturer's protocol. Contaminating genomic DNA was removed by treatment with RNase-free DNase I (Sigma) at $37^{\circ} \mathrm{C}$ for $1 \mathrm{~h}$. Total RNA amount was quantified by UV spectrophotometry at $260 \mathrm{~nm}$. All the RNA samples were adjusted to the same concentration for further use. The cDNA strands were generated by reverse transcribing $5 \mu \mathrm{g}$ of total RNA $(50 \mu \mathrm{l}$ reaction volume) using AMV reverse transcriptase (Takara Biotechnology, Shiga, Japan) at $42^{\circ} \mathrm{C}$ for $1 \mathrm{~h}$.

\section{Semi-quantitative RT-PCR}

The cDNA samples were diluted to $1 / 5,1 / 20$ and $1 / 100$. $1 \mu \mathrm{l}$ of each dilution and the undiluted sample was used as template for PCR quantification. The actin specific forward primer: 5'-CCATTGGTGCTGAGCGTT-3' and reverse primer: 5'-TAGGAATGGAAGCTGCGGG-3' were used to quantify the amount of amplico effective cDNA template. PCR was carried out as follows; $95^{\circ} \mathrm{C}$ for $3 \mathrm{~min}$; followed by 30 cycles of $94^{\circ} \mathrm{C}$ for $30 \mathrm{sec} ; 56^{\circ} \mathrm{C}$ for $30 \mathrm{sec}$ and $72^{\circ} \mathrm{C}$ for $30 \mathrm{sec}$; finally a extension of $10 \mathrm{~min}$. Precisely $5 \mu \mathrm{l}$ of each amplification was loaded on $1.5 \%(\mathrm{w} / \mathrm{v})$ agarose gel and the gel was stained by a $10 \mu \mathrm{g} / \mathrm{ml}$ ethidium bromide solution to visualize the bands. The gel was photographed by UV analysis system FR200A (Mikuni, Tokyo, Japan). The relative density of each band was measured by software Smart view ${ }^{\mathrm{TM}}$. The cDNA concentrations were normalized based on the concentration of actin. A pair of primers P-5: 5'-CTGCGTGTTGGAGTCAGGCG and P-2: 5'-CATTTGGTTCAGACTCGACCACAAC that were specific to the DNA binding domain of OsARF1 was applied for semi-quantitative RT-PCR. Each PCR reaction was performed in a $25 \mu$ l aliquot as follows; $95^{\circ} \mathrm{C}$ for $3 \mathrm{~min}$; followed by 30 cycles at $94^{\circ} \mathrm{C}$ for $30 \mathrm{sec} ; 60^{\circ} \mathrm{C}$ for $30 \mathrm{sec}$ and $72^{\circ} \mathrm{C}$ for $30 \mathrm{sec}$; finally with an extension of $10 \mathrm{~min}$. The following steps were the same as for actin quantification.

\section{Construction of antisense OsARF1 transgenic rice}

The original partial cDNA, corresponding to the full length coding sequence from $514 \mathrm{bp}$ to $1190 \mathrm{bp}$, was inversely inserted between BamHI and Sall site of the binary vector pBin438. Expression was driven by Cauliflower mosaic virus (CaMV) $35 \mathrm{~S}$ promoter and terminated by the nos terminator (Fig. 1A). The recombinant plasmid was transformed into rice embryogenic calli through Agrobacterium-mediated transformation as previously described (Sunilkumar et al., 1999). Transformed calli were inculcated into selection medium supplemented by kanamycin $(100 \mathrm{mg} / \mathrm{l})$ and incubated in the dark at $28{ }^{\circ} \mathrm{C}$ for 2 weeks. Resistant-calli were sub-cultured in differentiation medium to regenerate plantlets. Primary transformants were grown in the greenhouse at $30 \pm 2{ }^{\circ} \mathrm{C}$ during the day $\left(14 \mathrm{~h}\right.$ light) and $22 \pm 2^{\circ} \mathrm{C}$ during the night $\left(10 \mathrm{~h}\right.$ dark). When the $4^{\text {th }}$ leaf grew, the transformed plantlets were transplanted into the field for phenotypic analysis. The controls were treated under the same conditions.

\section{Northern hybridization analysis}

The whole plants at later vegetative stage were collected for RNA extractions. Total RNA $(30 \mu \mathrm{g})$ of each sample of the transgenic plants and controls were separated by electrophoresis in agarose-formaldehyde gels and transferred to positively charged nylon membranes (Boehringer, Mannheim, Germany). Hybridization was performed with Rapidhyb ${ }^{\mathrm{TM}}$ hybridization buffer (Amersham Piscataway, NJ, USA) at $65^{\circ} \mathrm{C}$ with a $\mathrm{y}-\left[{ }^{32} \mathrm{P}\right]-$ dCTP random-labeled probe corresponding to OsARF1 cDNA. After washing with $2 \times$ SSC, $1 \times$ SSC and $0.5 \times$ SSC washing solutions ( $1 \times$ SSC is $0.15 \mathrm{M} \mathrm{NaCl}, 0.015$ $\mathrm{M}$ sodium citrate) containing $0.2 \%(\mathrm{w} / \mathrm{v}) \mathrm{SDS}$ at $63{ }^{\circ} \mathrm{C}$, membranes were autoradiographed for 16-96 h using an intensifying screen (Biomax, Kodak,Rochester, NY).

\section{Microarray analysis}

Microarray analysis was carried out by Capital Biochip Corporation with hybridization tuned for gene expression variation (Lan et al., 2004). The RNA samples from 11 independent transgenic plants were quantified and evenly contributed to the RNA population for microarray 



Fig. 1. A Construction of binary vector pBin438 harboring the AS-cDNA of OsARF1 in the antisense orientation driven by $35 S$ promoter and Nos terminator. Kpn1 was within the selectable marker gene. B Structural features of OsARF1 gene. The exons and introns are represented by boxes and lines, respectively.

analysis. The RNA of untransformed plants was used as the control. Probe hybridization and scanning of the hybridized microarray slide were done according to the method of Lan, (2004). Hybridization was carried out twice and data were analyzed with ArrayGuage ${ }^{\mathrm{TM}}$ version 1.21 (Fujifilm, Tokyo, Japan).

\section{Results and discussion}

Structural features of OsARF1 gene

A cDNA of a rice ARF orthologue was isolated by subtractive suppressed hybridization (SSH), using a cDNA library of young panicles as tester and that of meritstems as driver (data not shown). The 5'-end and 3'- ends were cloned using RACE method (Subudhi and Huang, 1999). By screening a bacterial artificial chromosome (BAC) library of 'IR64 Indica' rice variety, a BAC clone containing the genomic DNA region corresponding to the cDNA was identified. The region of approximately $8 \mathrm{~kb}$ that encompassed the coding region was sequenced by primer walk sequencing. A rice marker RZ797, which mapped on chromosome 11, was within this region locating OSARF1. The full-length cDNA of the rice ARF1 gene was 2,559 bp; consisted of 14 exons; and encoded 852 amino acid polypeptides (Fig. 1B). Similarity searches indicated that the OsAFR1 gene was most closely orthologous to Arabidopsis ARF1. Therefore, 'Oryza sativa auxin response factor 1' (OsARF1; GenBank accession number AJ306306) was named according to the standard nomenclature. The deduced amino acid sequence of OSARF1 had the typical features of transcriptional factor, with a DNA binding domain (AuxRe) close to its $\mathrm{N}$ - terminal, and a protein interaction domain (Aux/IAA) at its $\mathrm{C}$ - terminal. However, the first 50 amino acid at $\mathrm{N}$ terminus and the mediate region between AuxRe and Aux/IAA showed low identities to any known ARF family gene (Fig. 1B).

\section{Expression pattern of OsARF1 gene in specific rice tissues}

The expression level of OsARF1 was extremely low so that it was not detected by Northern hybridization; even in young panicle where the gene was originally isolated. Consequently the OSARF1 transcript abundance patterns were analyzed using semi-quantitative RT-PCR. The 5' primer was designed to a region of OsARF1 sequence that was not conserved in other ARF or Aux/IAA genes. OsARF1 was transcript accumulated in callus and young panicle at much higher amount than in leaf and root. Compared to that in non-differentiated callus, the transcript abundance in differentiating callus dropped significantly (Fig. 2). The results suggested that OsARF1 could be associated with embryogenesis, because of the higher transcript abundance in young panicles and calli, which both are embryonic tissues.

AS-OsARF1 transgenic rice showed inhibited growth To investigate the effects of the loss of function of the OsARF1 gene on rice phenotypic characters, the ASOsARF1 vector was constructed and transferred to the rice cells using Agrobacterium-mediated transformation technique. The transgeneic plants were detected by PCR using non-intron sequence specific forward primer P-5.7: 5'-AAATGGCGCTCCCTTAAGGTGAG and the reverse primer P-2: 5'-CATTTGGTTC GACTCGACCACAAC. Eleven of 16 regenerated rice plants showed the

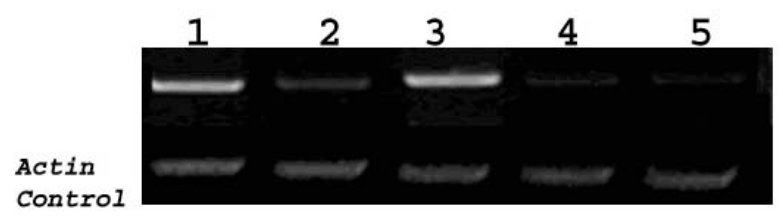

Fig. 2. Transcript abundance of OsARF1 in wild type rice. Lanes were; 1. embryogenic callus; 2. differentiating callus; 3. young panicles; 4. leaves; 5. roots. Lower lanes: Actin mRNAas a control. 


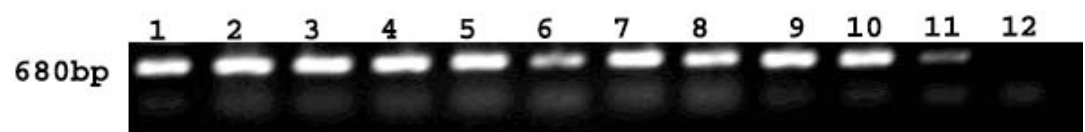

Fig. 3. Detection of AS-OSARF1 integration by non-intron sequence specific primers. Lane 1-11: AS-OsARF1 transformed regenerated plants; Lane 12: control plant.

expected amplicons (680 bp) while there was no signal in the control, indicating that the AS-OSARF1 cDNA was successfully integrated into the genome of transgenic plants (Fig. 3). The AS-OSARF1 transformed plants showed significantly lower growth and vigor that included smaller leaves and shorter heights, compared to nontransformed plants. Interestingly, the length of the tillering node didn't change significantly in transgenic plants (Fig. 4). Also, the leaves curled across the width. Eight of 11 transgenic plants failed to head and the remaining three were sterile, although they were able to develop to the heading stage 13-15 days later than the non-transformed plants. Hence, no $\mathrm{F}_{2}$ progeny was obtained. In order to investigate the transcript abundance of $A S-O S A R F 1$, total RNA was isolated from transgenic and control plants and subjected to RNA gel blot analysis. The result showed that there was extremely low level of mRNA in control and transgenic plants (Fig. 5).

\section{Microarray analysis of regulated genes expression in transgenic plants}

To test the changes in gene expression caused by OsARF1 in transgenic plants, microarray analysis was conducted. Genomic transcript abundances pattern in the transgenic plants was checked with a cDNA microarray containing 14,688 genes arrayed in duplicates that were randomly selected from rice ESTs library (http://microarray.rice.dna. affrc.go.jp). Microarray analysis of the transgenic plants in later vegetative stages showed that 10,325 genes of

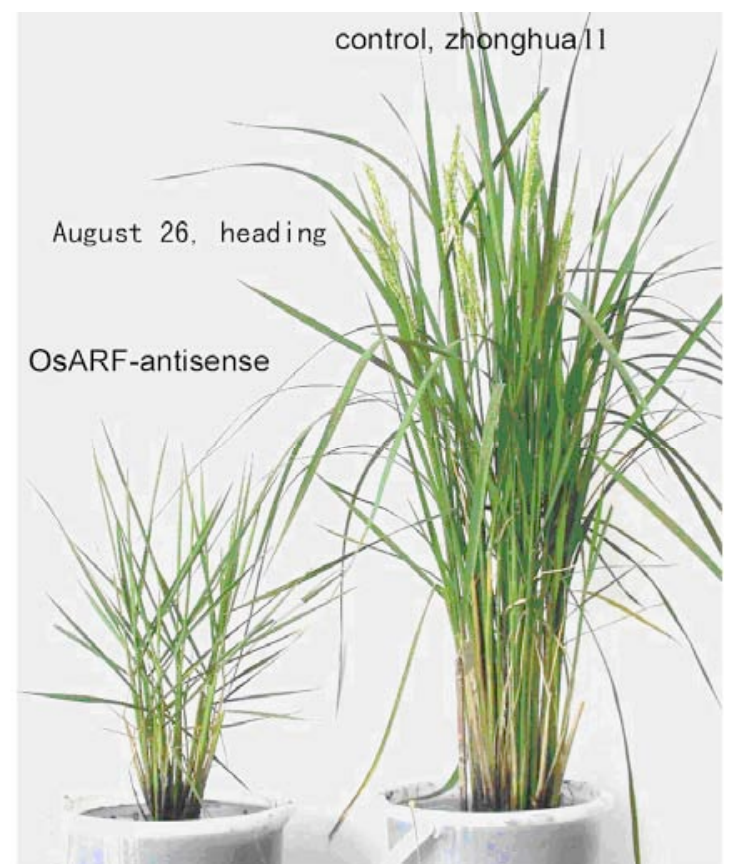

Fig. 4. Comparison of $A S-O S A R F 1$ transgenic rice and a non transgeneic control. Left; AS-OsARF1 transgenic rice. Right; untransformed control. the total of 14,688 genes were expressed at this stage in transgenic plants (Fig. 6A). The genes whose florescent ratio was $<0.5$ or $>2.0$ (transgenic/control) were defined as differently expressed genes. By this criterion, 435 genes were differently expressed, 255 of them were down regulated (Fig. 6B) and 180 were up regulated (Fig. 6C). The annotated genes were located in 9 sub-categories of molecular functions in gene ontology (Table 1). Most of the differently expressed genes were categorized among those encoding proteins with catalytic activity. However, the inference of gene function based on homology and annotation may not reflect the real function, thus the classification of these genes was only a reference.

In this study, "knock down" phenotypic analysis was used. Phenotypes were clear and consistent but unlike those seen from ortholgues in $A$. thaliana. Semiquantitative RT-PCR showed that no transcript of the original OsARF1 was detected in AS-OsARF1 transgenic plants, suggesting that the AS-RNA not only inhibited the translation of its target mRNA, but also caused degradation of target mRNA. So, AS-RNA might work in a similar way as RNAi (RNA interference). Recently, it was reported that the expression of OsARF1 was positively regulated by auxin concentration (Waller et al., 2002). However, the expression level of ARF1 in Arabidopsis was relatively consistent regardless the concentration of auxin (Ulmasov et al., 1997a). That suggested that the OsARF1 might not be the exact ortholog of AtARF1 even though these two genes shared the highest degree of similarity between rice and Arabidopsis (Frank et al., 2002). Here, OsARF1 was expressed significantly higher in embryonic tissues (callus and young panicle) than that in non-embryonic tissues (root, leaf and differentiating callus). Therefore the endogenous auxin to cytokinin ratio might be higher in embryonic tissues. In addition, the increasing of the expression of OsARF1 could be essential to embryogenesis since all the AS-OsARF1transgenic plants were sterile. OsARF1, as an early response gene in auxin signaling (Waller et al., 2002) might play a key role in fertility and regulate quite a few downstream genes associated with growth and reproduction.

The cDNA microarray provided an efficient high throughput approach to investigate the function of a large numbers of genes and their expression in response to environmental effects (Kawasaki et al., 2001). The results

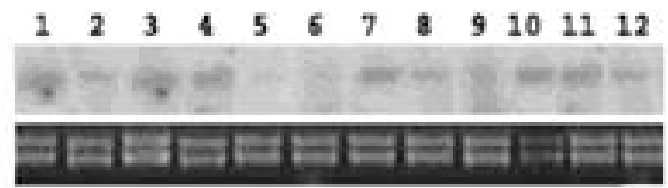

Fig. 5. Abundances of the AS-OSARF1 mRNA in transgenic rice plants. Upper panel: Lane 1: control; lanes 2-12: 11 transgenic plants. Lower panel: rRNA control. 
A

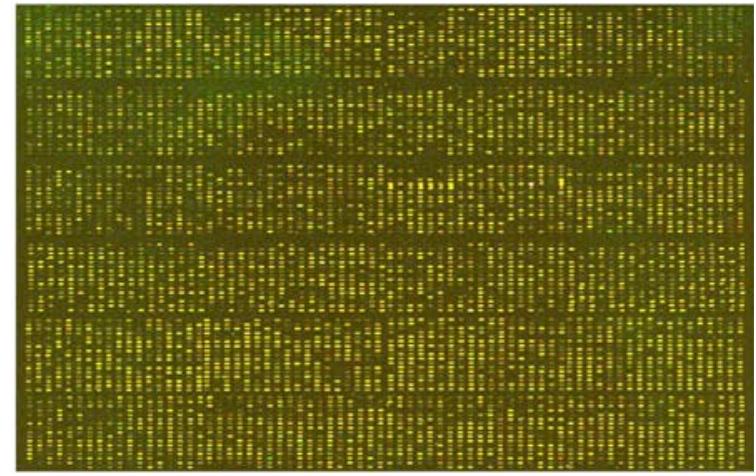

B
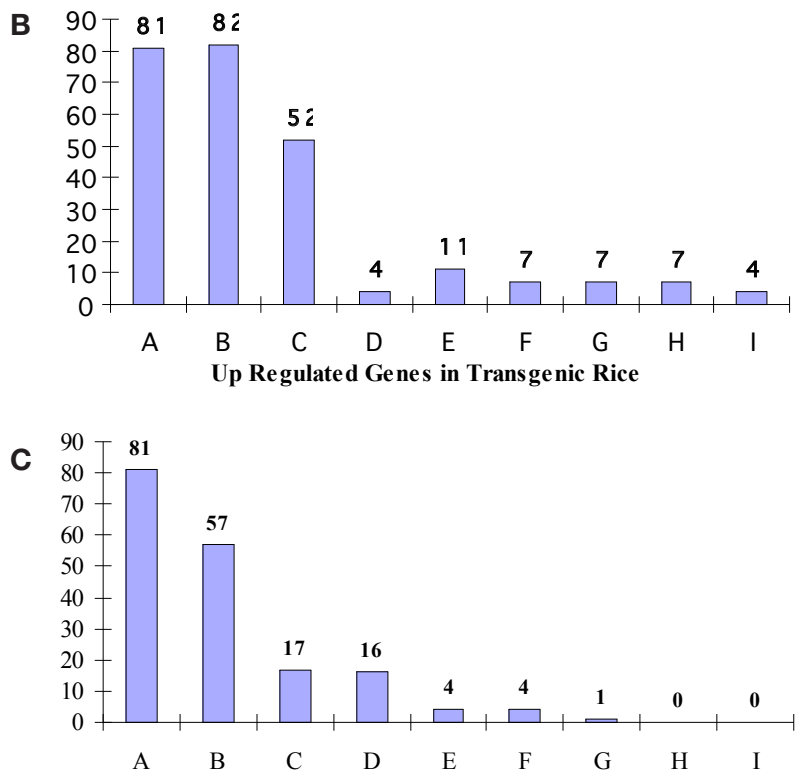

Fig. 6A. Microarray analysis of regulated transcript abundance among transgenic plants. Three-color image of a transgenic plant cDNA array. After scanning for each fluorescent dye separately false colour images were superimposed. Red dots correspond to genes higher expressed down-regulation, green dots to genes that are higher expressed upregulation, and yellow dots represent genes that show no differentia expression. B Genes decreased in TA in transgenic rice. Alphabetic letters represent indicators in Table 1. C Genes increased in TA in transgenic rice. Alphabetic letters represent indicators in Table 1. here indicated that approximately $3 \%$ of the total set of predicted genes and approximately $4 \%$ of known to be expressed genes showed significant differences among their transcriptional abundance between the transgenic plants and the controls. The ratio of differently expressed genes was similar among different tissues. Reproductive stage analyses were not possible because all AS plants failed to reach to productive growth stage. It seems likely the knock down of OsARF1 turned off some key switches for transformation from vegetative stage to the reproductive stage. Perhaps OsARF1 itself was the switch. Suppression of OsARF1 expression also caused dramatically growth at vegetative stages, even though its expression was extremely low at this stage in wild type rice. This demonstrates that, perhaps OsARF1 is crucial to all growth. In comparison the phenotypic effect of ARF1 in Arabidopsis is unknown (Wang et al., 2007). In contrast, OsARF1 was shown to be essential for the developmental growth stages of the life cycle of the rice plant. The pathways and functional mechanisms will be studied further.

\section{References}

Akila, O., Danielle, C., Alain, D.M., Yves, D., Jean, B., and Mercè, B. (2004) The T-DNA ORF8 of the cucumopinetype Agrobacterium rhizogenes Ri plasmid is involved in auxin response in transgenic tobacco. Plant Sci. 166, 557-567.

Wang, D., Kemei, P., Yaping, F., and Zongxiu, S. (2007) Genome-wide analysis of the auxin response factors (ARF) gene family in rice (Oryza sativa) Gene 394, 13-24.

Frank, W., Masaki, F., and Peter. N. (2002) OsARF1, an auxin response factor from rice, is auxin-regulated and classifies as a primary auxin responsive gene. Plant Mol. Biol. 50, 415-425.

Kawasaki, S., Borchert, C., Deyholos, M., Wang, H., Brazilla, S., Kawai, K., Galbraith, D., and Bohnert, H. (2001) Gene expression profile during the initial phase of salt stress in rice. Plant Cell 13, 889-905.

Lan, L., Chen, W., Lai, Y., Suo, J., Kong, Z., Li, C., Lu, Y., and Zhang, Y. (2004) Monitoring of gene expression profiles and isolation of candidate genes involved in

Table 1. Genes with different transcript abundances detected by cDNA microarray.

\begin{tabular}{llccc}
\hline & Differently expressed genes & & & \\
No. & Categorization of expressed genes & Down-regulated genes & Up-regulated genes & Total numbers of expressed genes \\
\hline A & No significant homology in GenBank & 81 & 81 & 162 \\
B & Homology to function unknown genes & 82 & 57 & 139 \\
C & Catalytic activity & 52 & 17 & 69 \\
D & Structural molecule activity & 4 & 16 & 20 \\
E & Transporter activity & 11 & 4 & 15 \\
F & Binding & 7 & 4 & 11 \\
G & Antioxidant activity & 7 & 1 & 8 \\
H & Enzyme regulator activity & 7 & 0 & 7 \\
I & Signal transducer activity & 4 & 0 & 4 \\
Total & & $\mathbf{2 5 5}$ & $\mathbf{1 8 0}$ & 435 \\
\hline
\end{tabular}


pollination and fertilization in rice ( Oryza sativa $L$.) with a 10K cDNA microarray. Plant Mol. Biol. 54, 471-87.

Okushima, Y., Overvoorde, P.J., Arima, K., Alonso, J.M., and Chan, A. (2005) Functional Genomic Analysis of the AUXIN RESPONSE FACTOR Gene Family Members in Arabidopsis thaliana: Unique and Overlapping Functions of ARF7 and ARF19. Plant Cell 17, 444-63.

Ozga, J.A., Huizen, R., and Reinecke, D.M. (2002) Hormone and seed-specific regulation of pea fruit growth. Plant Physiol. 128, 1379-89.

Remington, D.L., Visionm, T.J., Guilfoylem, T.J., and Reed, J.W. (2004) Contrasting models of diversification in the Aux/IAA and ARF gene families. Plant Physiol. 135, 1738-1752.

Subudhi, P.K., and Huang, N. (1999) RAPD mapping in a doubled haploid population of rice (Oryza sativa L.) Hereditas 130, 41-9.

Sunilkumar, G., Vijayachandra, K., and Veluthambi, K. (1999) Pre-incubation of cut tobacco leaf explants promotes Agrobacterium-mediated transformation by increasing vir gene induction. Plant Sci. 141, 51-58.

Ulmasov, T., Liu, Z.B., Hagen, G., and Guilfoyle, T.J. (1995) Composite structure of auxin response elements. Plant Cell 7, 1611-1623.

Ulmasov, T., Hagen, G., and Guilfoyle, T.J. (1997a) ARF1, a transcription factor that binds to auxin response elements. Sci. 276, 1865-1868.

Ulmasov, T., Hagen, G., and Guilfoyle, T.J. (1999) Activation and repression of transcription by auxinresponse factors. PNAS 96, $5844-5849$.

Ulmasov, T., Hagen, G., and Guilfoyle, T.J. (1999a) Dimerization and DNA binding of auxin response factors. Plant J. 19, 309-319.

Waller, F., Furuya, M., and Nick, P. (2002) OsARF1, an auxin response factor from rice, is auxin-regulated and classifies as a primary auxin responsive gene. Plant Mol. Biol. 50, 415-25. 


\section{Further Reading}

Caister Academic Press is a leading academic publisher of advanced texts in microbiology, molecular biology and medical research. Full details of all our publications at caister.com

- MALDI-TOF Mass Spectrometry in Microbiology Edited by: M Kostrzewa, S Schubert (2016) www.caister.com/malditof

- Aspergillus and Penicillium in the Post-genomic Era Edited by: RP Vries, IB Gelber, MR Andersen (2016) www.caister.com/aspergillus2

- The Bacteriocins: Current Knowledge and Future Prospects Edited by: RL Dorit, SM Roy, MA Riley (2016)

www.caister.com/bacteriocins

- Omics in Plant Disease Resistance Edited by: V Bhadauria (2016) www.caister.com/opd

- Acidophiles: Life in Extremely Acidic Environments Edited by: R Quatrini, DB Johnson (2016) www.caister.com/acidophiles

- Climate Change and Microbial Ecology: Current Research and Future Trend

Edited by: J Marxsen (2016)

www.caister.com/climate

- Biofilms in Bioremediation: Current Research and Emerging Technologies

Edited by: G Lear (2016)

www.caister.com/biorem

- Microalgae: Current Research and Applications Edited by: MN Tsaloglou (2016) www.caister.com/microalgae

- Gas Plasma Sterilization in Microbiology: Theory, Applications, Pitfalls and New Perspectives Edited by: H Shintani, A Sakudo (2016) www.caister.com/gasplasma

- Virus Evolution: Current Research and Future Directions Edited by: SC Weaver, M Denison, M Roossinck, et al. (2016) www.caister.com/virusevol

- Arboviruses: Molecular Biology, Evolution and Control Edited by: N Vasilakis, DJ Gubler (2016) www.caister.com/arbo

- Shigella: Molecular and Cellular Biology Edited by: WD Picking, WL Picking (2016) www.caister.com/shigella

-Aquatic Biofilms: Ecology, Water Quality and Wastewater Treatment

Edited by: AM Romaní, H Guasch, MD Balaguer (2016)

www.caister.com/aquaticbiofilms

- Alphaviruses: Current Biology

Edited by: S Mahalingam, L Herrero, B Herring (2016)

www.caister.com/alpha

- Thermophilic Microorganisms

Edited by: F Li (2015)

www.caister.com/thermophile
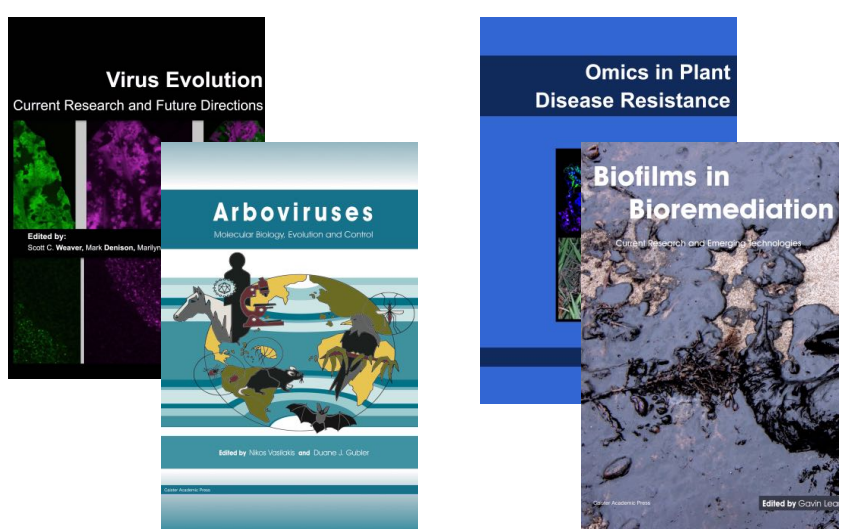
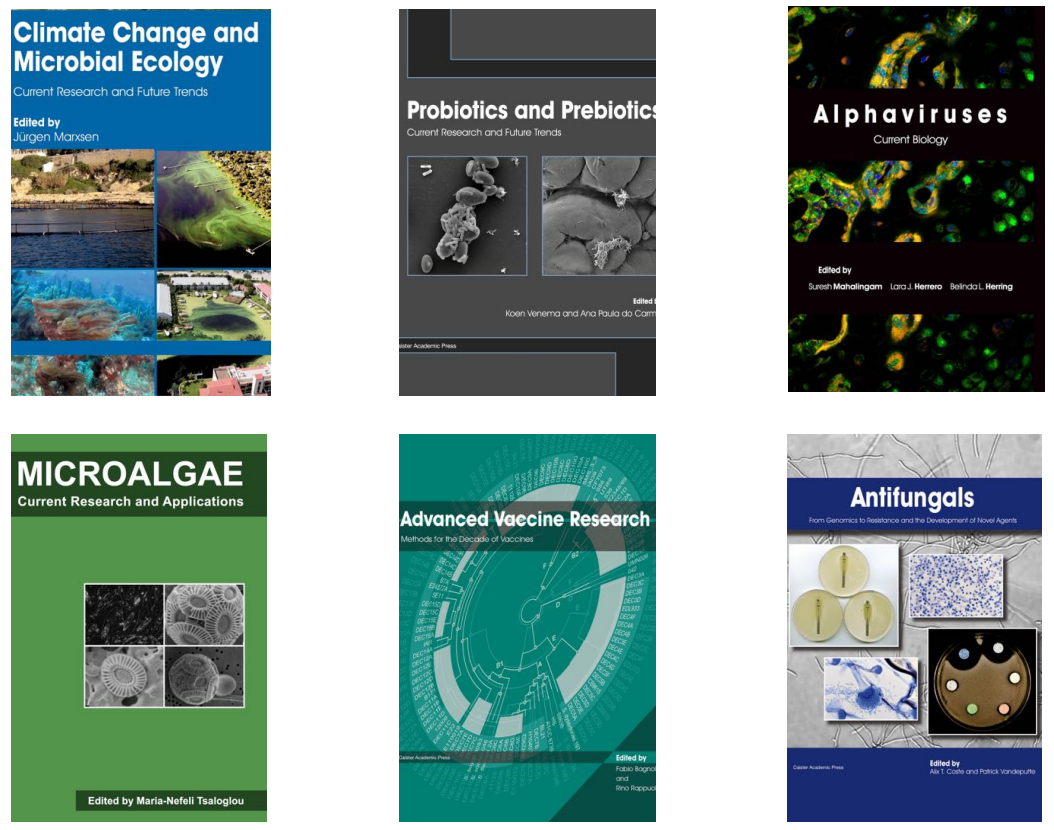

- Flow Cytometry in Microbiology: Technology and Applications Edited by: MG Wilkinson (2015) www.caister.com/flow

- Probiotics and Prebiotics: Current Research and Future Trends Edited by: K Venema, AP Carmo (2015) www.caister.com/probiotics

- Epigenetics: Current Research and Emerging Trends Edited by: BP Chadwick (2015) www.caister.com/epigenetics2015

- Corynebacterium glutamicum: From Systems Biology to Biotechnological Applications

Edited by: A Burkovski (2015)

www.caister.com/cory2

- Advanced Vaccine Research Methods for the Decade of Vaccines

Edited by: F Bagnoli, R Rappuoli (2015)

www.caister.com/vaccines

- Antifungals: From Genomics to Resistance and the Development of Novel Agents

Edited by: AT Coste, P Vandeputte (2015)

www.caister.com/antifungals

- Bacteria-Plant Interactions: Advanced Research and Future Trends Edited by: J Murillo, BA Vinatzer, RW Jackson, et al. (2015) www.caister.com/bacteria-plant

\section{- Aeromonas}

Edited by: J Graf (2015)

www.caister.com/aeromonas

- Antibiotics: Current Innovations and Future Trends

Edited by: S Sánchez, AL Demain (2015)

www.caister.com/antibiotics

- Leishmania: Current Biology and Contro Edited by: S Adak, R Datta (2015) www.caister.com/leish2

- Acanthamoeba: Biology and Pathogenesis (2nd edition) Author: NA Khan (2015)

www.caister.com/acanthamoeba2

- Microarrays: Current Technology, Innovations and Applications Edited by: Z He (2014)

www.caister.com/microarrays2

- Metagenomics of the Microbial Nitrogen Cycle: Theory, Methods and Applications

Edited by: D Marco (2014)

www.caister.com/n2 